\title{
A Study of Management Corporation Financial in High Rise Residential with Correlation of Management Fund and Facilities Provided
}

\author{
N.M. Tawil, Y.Md. Yusoff, A.I. CheAni, N.A.G. Abdullah and M. Surat \\ Department of Architecture, Faculty of Engineering and Architecture, \\ Universiti Kebangsaan Malaysia, 43600 UKM Bangi, Selangor Darul Ehsan, Malaysia
}

\begin{abstract}
Housing plays an important role in property finance for national economic point of view. It is a long term investment which becomes source of income for many parties. In recent years, most of urban areas in Malaysia are looking forward to live in stratified unit compared to other types of housing. Limitation of land availability and increasing of property value have contributes to more construction and development on high rise residential. This residential type is more economical compared to landed property. In the other hand, each complex of high residential building needs a body to manage all shared-property such as facilities, road and pathway, lighting and so on which namely Management Corporation (MC). Many researches have been conducted to determine the problems faced by MC in managing highrise residential matters. The most common problem faced by $\mathrm{MC}$ is poor collection of maintenance fund. Thus, it was effecting the management financial. The tenant refuses to pay the maintenance fund due to dissatisfaction of work done by MC. Briefly, this study explained the determination of actual amount of maintenance fund to be applied to high rise tenants according to facilities provided. The study employed questionnaires to obtain information from fifty tenants of different residential areas around Klang valley, Malaysia. From the questionnaires, a few data were collected such as strata type, price of house unit, price of maintenance fee and type of facilities provided. The result of this research, it found that determination of maintenance fund price was subjected to facilities provided in the residential area.
\end{abstract}

$\underline{\text { Key words: Management fund, facilities, high rise residential, property finance, fee, Malaysia }}$

\section{INTRODUCTION}

Housing is needed by everyone in this world as shelter. Housing is also one of the bigger property that needed by a man. This is because housing is not just a physical structure that provides protection to the occupants but also closely linked with socio-economic, political, neighbourhood and environment (Bourne, 1981). According to Ball and Grill (1997), housing is very important to a country's economy because housing is a consumer and almost $15-30 \%$ of household spending in the European Union was related with housing matter. In addition, it is also important investment where $5 \%$ of country income invested in housing industry. Nevertheless, the affordable issues arise when it is due to middle income group (Musa et al., 2011; Suhaida et al., 2011). Related to property finance inssues man will definitely find a house that suitable with the affordability of income. Increasing of housing demand in Malaysia was affecting property market prices. When the land is scarce land value/price is automatically increased
(Ariyawansa and Udayanthika, 2012). Balancing in the housing market is difficult to achieve because of the demand and housing supply is not only influenced by price alone but also by other factors such as economic, social, political, legal and technological change.

Therefore, housing construction in urban areas is changing to the development of vertically than horizontally (Tawil et al., 2009). This is because constructing stratified housing is more economical and affordable compared to landed housing. According to The Malay Mail, February 6, 2010 until December of 2009, 12,000 high rise residential projects consists of 1.2 million housing units were constructed. This amount can accommodate about 5-6 million people. According to the Tiun (2006), the concept of high rise or stratified residential is not something new. He also stated that the concept of strata have been introduced in year of seventies in penang. So, it is clear that Malaysia is able to receive this type of development. This type of residential is consists of many owners in a same lot. Life in strata type of residential needs the owner to share management

Corresponding Author: N.M. Tawil, Department of Architecture, Faculty of Engineering and Architecture, Universiti Kebangsaan Malaysia, 43600 UKM Bangi, Selangor Darul Ehsan, Malaysia 
and facilities together. It is different compared to life of people who live in other types of residential because of the characteristics of partnership (Tawil et al., 2008). Many problems have created in strata type of residential. Therefore, a corporation is required in managing and maintaining building matters such as shared property, parking, pedestrian area, lighting in public area and corridors and a few more public facilities in the residential building. A strong and enough financial is needed to ensure that maintenance works are carried out consistent, meets the required standards and fulfilled the legal requirements have been outlined (Tawil et al., 2011).

Payment of maintenance fee by tenants is very important. In other hand, payment of maintenance fee is the main source to pay all maintenance works and services.

The high rise residential management and maintenance are required a relatively high cost. This scenario makes the most of the tenants often complain that the maintenance fees imposed are too high without knowing the uses and flows of the money paid. Therefore, it became responsibility of the Management Corporation (MC) to determining a realistic management costs and find out alternatives way to save on maintenance costs.

Facilities and management corporation facilities: Every high rise residential complex has at least one facility provided to the owner. The developers offer a variety of amenities and facilities for each high rise residential development to attract buyer. According to the Tiun (2006), buyers tend to choose and have a good quality of life. It is not only the physical of a house but also a complete housing package like security, swimming pool, covered parking and self privacy. The body who is responsible in managing the maintenance work is the management corporation. According to Leong (2000), there are several common types of facilities are provided in high rise residential at Klang valley. The types of facilities in stratified residential are as:

\begin{tabular}{ll}
\hline Facilities & Facilities \\
\hline 24 h security & Laundry \\
Lifts & Covered parck \\
Play ground & Swimming pool/wading pool \\
Cafeteria & Sauna \\
BBQ area & Jacuzzi \\
Nursery & Yoga room/tai chi area \\
Jogging track & Gymnasium \\
Mini market & Karaoke room \\
Reading room & Basket ball court \\
Table tennis room & Prayer room \\
Wi-Fi room & Salon/beauty centre \\
Multi-purpose hall & Tennis/squash court \\
\hline
\end{tabular}

According to Azmi (2006), many of the common facilities such as lifts, swimming pool, gymnasium, tennis court, landscaped garden and even security services are expensive to be maintain. With a good collections of maintenance fee, $\mathrm{MC}$ are able to carry out their job to make sure all facilities work accordingly.

Management Corporation (MC): Refer to Garis Panduan Perbadanan Pengurusan dan Pentadbiran Skim Strata Menurut Kuatkuasa AktaHakmilik Strata in 1985, Pindaan in 2007, management corporation is automatically formed when strata register book was opened on the date of its memorial endorsement was registered in document of land title on any building has been sub-divided while the blocks and/or parcels of land (land parcels) is situated. Management Corporation (MC) is an organization that has been gazetted in the Strata Titles Act 1985 for all high rise buildings.

$\mathrm{MC}$ is the responsible body who will maintain and manage all cases in strata type property. In the same time, $\mathrm{MC}$ is also responsible for ensuring that people pay maintenance on time. This is to ensure the stability of maintenance financial of the corporation thus prevent the occurrence of any problems in carrying out maintenance work on residential buildings.

According to Azmi (2006), in the sales and purchase agreement, it is stated that the purchaser shall be liable for and shall pay for the service charges for the maintenance and management of the common property and for the services provided by the developer prior to the establishment of a management corporation under Strata Title Act, 1985. That mean, every one need to co-operate to management corporation by settle-up maintenance fee to ensure maintenance work in running well. Unfortunately, different background of the owner lead to misconception of sharing facilities and sharing responsible towards maintaining the common properties. Some of the owner refuse to pay the fees since they did not use the facilities or did not satisfied with the quality of service. Some of them claim that they need to know the breakdown of the fees towards facilities and management. The purpose of this research is to look into the relationship in between the facilities provided and the service charge amount in high-rise residential in greater city Kuala Lumpur.

\section{MATERIALS AND METHODS}

This research involves only 2 states which is Kuala Lumpur and Selangor. These 2 districts are located in areas within the Klang valley, Malaysia. These areas were selected because it have a higher number of high rise 


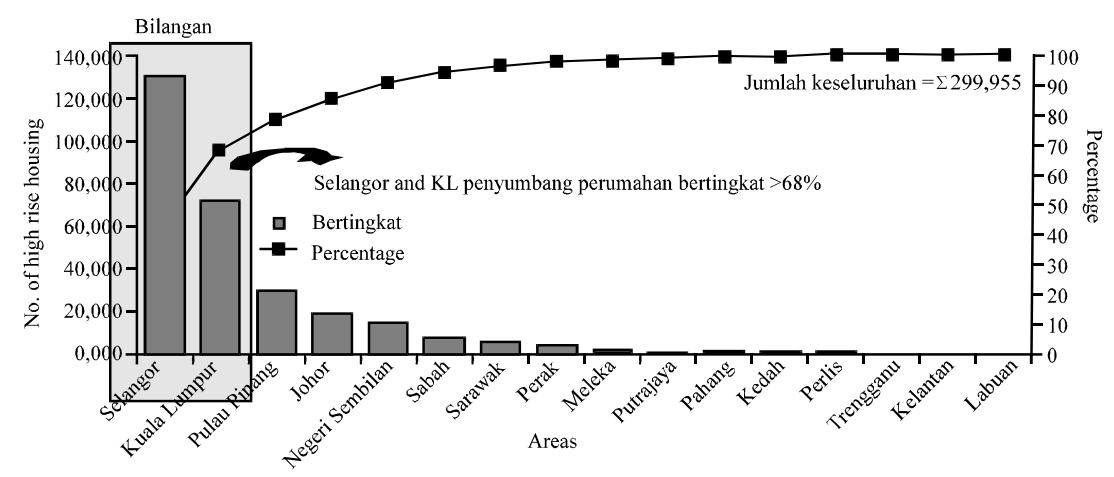

Fig. 1: Number of high rise housing have done in year 2002-2006

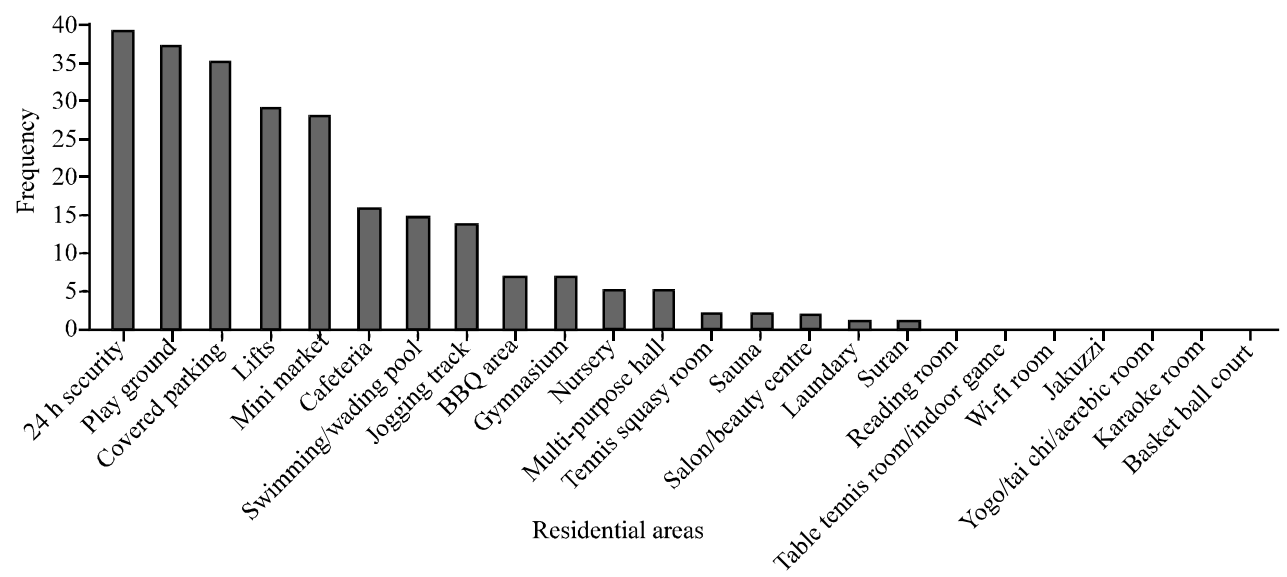

Fig. 2: Graph of facilities frequency in 46 high rise residential area

residential compared to other states. Figure 1 shows the Pareto graph of the number of successfully completed high rise housing from 2002-2006 in Malaysia. Selangor recorded the largest number which is $44 \%$ while Kuala Lumpur recorded the second largest number which is $22 \%$. This shows that Selangor and Kuala Lumpur are the states with many high rise housing in Malaysia.

Primary data was collected from 100 high rise residential areas which are located around Klang valley and Kuala Lumpur. Interviews were conducted with the tenant using structured questionnaires. They were interviewed inquiring few aspects; price of the house, price of the maintenance fee and facilities available in their residential area. About 46 from 100 that were recorded have to pay RM100 below for maintenance fee.

\section{RESULTS AND DISCUSSION}

Preliminary study: Questionnaire was conducted 100 of tenants from different high rise residential areas around Klang valley and Kuala Lumpur. This study focused on residential areas with maintenance fee of RM100 and below. From 100 data of the respondents, 46 respondents of that are having monthly maintenance fee of below RM100 and other 54 respondent is between RM100-350 monthly. Figure 2 shows the percentage of frequency facilities available in 46 different high rise residential areas by type offacilities.

From Fig. 2, 84.78\% residential areas provide $24 \mathrm{~h}$ security and $80.43 \%$ provide playground. About $76.09 \%$ are having covered area to park their car and $63.04 \%$ have lifts in their residential building. About $34.78 \%$ have mini market and $34.78 \%$ have cafeteria.

Only $32.61-30.43 \%$ were served with swimming pool and jogging track. Same number, $15.22 \%$ from 46 residential provide $\mathrm{BBQ}$ area and gymnasium for their tenants and $10.87 \%$ provide multi-purpose hall and nursery at their residential area. The $4.35 \%$ residential have salon or beauty centre, sauna and tennis and squash court.

Only $2.17 \%$ from 46 residential areas serve their tenant with surau and laundry. All of the 46 residential areas have no other facilities like reading room, tennis and indoor room, Wi-Fi room, Jacuzzi, Yoga/tai chi/Aerobic room, karaoke and basket ball court. From the data analysis, the study found that a large amount of the 
maintenance money were paid by the tenants was used for $24 \mathrm{~h}$ security. This is because 24 security needs monthly stable financial to pay labours service like security guards. Other facilities like playground, tennis/squash court and surau were not need labour service. Some of facilities such as playground, tennis/squash court, $\mathrm{BBQ}$ area, sauna and surau need minor maintenance such as cleaning services and some repair works. While some others facilities such as lifts and gymnasium need major maintenance intention and it took a large amount from maintenance fee to pay all service works. A consistent payment of monthly maintenance fees by the tenants are needed to make sure all service and maintenance works can be done accordingly. All facilities need to maintain to ensure a better and performance.

\section{CONCLUSION}

The actual value of the fund price should be adjusted according to the management of quantity and quality of facilities provided by the management. This is important to ensure the tenants of high rise residential are satisfied with the money they spent for management fund fees. In addition, the actual values of the management fund price also able to clear-up people sceptical toward the flow of money paid to $\mathrm{MC}$.

\section{ACKNOWLEDGEMENT}

This research is acknowledged by research grant UKM-GGPM-NBT-165-2010.

\section{REFERENCES}

Ariyawansa, R.G. and A.G.P.I. Udayanthika, 2012. Living in high-rise: An analysis of demand for condominium properties in Colombo. Int. J. Soc. Anthropol., 4: 31-37.
Azmi, N.A.A.L., 2006. The study of problems faced by property management in managing the high rise condominium in Malaysia. Master's Thesis, Universiti Teknologi Malaysia, Malaysia.

Ball, M. and M. Grill, 1997. Housing Markets and Economic Convergence in the European Union. Royal Institution of Chartered Surveyors, UK., ISBN: 9780854068319, Pages: 52.

Bourne, L., 1981. The Geography of Housing. Edward Arnold, London.

Leong, A., 2000. Guide to Condominium and Apartment in the Klang Valley. Leeds Pub., Malaysia, ISBN: 9789839839852, Pages: 280.

Musa, A.R., N.M. Tawil, S.M. Sood, A.I. Che-Ani, N. Hamzah and H. Basri, 2011. Constructing formulation of affordable green home for middle income group. Procedia Eng., 20: 466-473.

Suhaida, M.S., N.M. Tawil, N. Hamzah, A.I. Che-Ani, H. Basri and M.Y. Yuzainee, 2011. Housing affordability: A conceptual overview for house price index. Procedia Eng., 20: 346-353.

Tawil, N.M., M.N. Daud, A.I. Ani, A. Ramly and H.N. Che, 2008. Managing indebtedness maintenance charges in high rise residential by lumpsum deposit management fund. Proceedings of International Real Estate Research Symposium, April 28-29, 2008, Putra World Trade Centre, Kuala Lumpur, Malaysia.

Tawil, N.M., A. Ramly, A.I. Che-Ani, I.M.S. Usman, M.M. Tahir, M.F.M. Zain and A. Zaharim, 2009. Service charge collection of high-rise residential in Kuala Lumpur, Malaysia: Owner's perspective. Eur. J. Soc. Sci., 10: 7-12.

Tawil, N.M., A.I. Che-Ani, A. Ramly, M.N. Daud and N.A.G. Abdullah, 2011. Service charge issue in Malaysian high-rise residential management: An analysis using a fuzzy conjoint model. Int. J. Phys. Sci., 6: 441-447.

Tiun, L.T., 2006. Managing high-rise residential building in Malaysia: Where are we? Proceedings of the 2nd NAPREC Conference on INSPEN, August 8-10, 2006, Universiti Putra, Malaysia. 